\title{
Profanity and Play: Solidarity in the Discourse of Cyberbullying
}

\author{
Jeremy Jones ${ }^{1}$ \\ ${ }^{1}$ University of Canberra, Australia \\ Correspondence: Jeremy Jones, University of Canberra, Australia. E-mail: Jeremy.Jones@canberra.edu.au
}

Received: October 20, 2021

Accepted: November 30, $2021 \quad$ Online Published: December 7, 2021

doi:10.5539/ijel.v12n1p120

URL: https://doi.org/10.5539/ijel.v12n1p120

\begin{abstract}
Offering the world countless remarkable benefits, computer mediated communication has become an essential feature of modern life. However, it has also become a medium for personal aggression and abuse of diverse kinds. The discourse of online vilification has been the topic of much research, for instance on the behaviour of trolls. This study focuses on a little researched phenomenon, the discourse of cyberbullying, in particular a subtype, cybermobbing, in which a group of participants gather online to attack an individual over a period of time. The study takes up an example of such participants who joined a Facebook group dedicated to abusing a prominent sportsman. The purpose of the study is to identify the chief discourse characteristics of cybermobbing that bind the participants together. The analysis reveals a high degree of solidarity among the participants expressed through profanity, humour, and play. The results will also throw light on the mentality of those who engage in cybermobbing.
\end{abstract}

Keywords: Antagonism, bullying, cyberbullying, cybermobbing, (im)politeness, Facebook

\section{Introduction}

The internet has transformed human society with its many and vast benefits. One such benefit is computer-mediated communication (CMC), a tool now totally indispensable for efficiency of work and a necessity for numerous forms of social encounter. Yet, as commonly lamented today, the internet has become a place for people to attack one another. It was not long after the founding of the World Wide Web in 1989, for example, that disruptive behaviour became evident. "Flaming" is one example, defined by Miller (1993) as aggressive or rude interaction in CMC. At the turn of the century, "trolls" emerged. According to Hardaker (2010), a troll is one who insinuates him or herself into a group and gains members' confidence but whose true intention is "to cause disruption and/or exacerbate conflict for the purposes of their own amusement" (p. 237). Hardaker (2010), who was writing about trolling in asynchronous CMC, adds the following reflection: “... part of the human condition is to find a degree of entertainment in conflict" (p. 238). It will be seen that these words have particular significance for the present study.

The advent of social media has provided terrain for new forms of aggression, or simply old forms facilitated by the medium. Jon Ronson, in his book So You've Been Publicly Shamed (2012) offers an illustration of the type and severity of online attacks. He recounts the story of a young American woman, Justine Sacco, a public relations consultant with a firm in New York, who liked to tweet quips to her 170 followers on her holiday experiences. The tweet in Figure 1 is one that was sent in transit at London's Heathrow airport on her way to Cape Town.

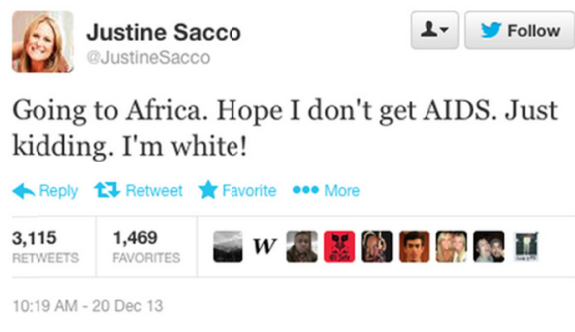

Figure 1. Original tweet from Justine Sacco 
She later explained that she had intended it as a joke, but by the time she arrived at her destination a twitter mob had formed denouncing her as a racist. One tweet was "Everyone go report this cunt @JustineSacco" (p. 50). The torrent included an appalled comment from her employers and the following: "We are about to watch this @.JustineSacco bitch get fired. In REAL time. Before she even KNOWS she's getting fired" (p. 51). Ronson remarked, "Justine Sacco felt like the first person I ever interviewed who had been destroyed by us" (p. 51).

This is a study of aggressive behaviour in CMC. The nature of this aggression is analysed through the discourse of the aggressors themselves, who act as a bullying group, a "mob" in effect. Belonging to a Facebook group, the participants, all rugby league enthusiasts, united to vilify a well-known professional player, Todd Carney. Like Sacco, he attracted a relentless outpouring of hostility, often vicious, as a result of bad behaviour; unlike her, however, he was not destroyed. The aggressors together created a lengthy text that presents opportunities to observe features that commonly interest the analyst of discourse: organisation and sequencing; coherence; and interaction, including turn-taking, particularly of an asynchronous nature. The expressions of abuse in the attackers' behaviour, with a recurrence of profanity, evoke a context of impoliteness. This study seeks to analyse the features of such abuse and show how they give the participants their solidarity.

\section{Conceptual Background}

\subsection{Defining Bullying, Cyberbullying, Mobbing, and Cybermobbing}

The text under analysis in this study shows a group of people, over several months, relentlessly attacking one individual on a Facebook site. The behaviour of these people seems to be characteristic of bullying. The common knowledge is that bullying involves one more powerful person seeking to do harm to another, weaker person over time (Nansel, Overpeck, \& Pilla, 2001) through either verbal or physical means, or a combination of both. Wierzbicka (2009), a linguist with an interest in the definition of bullying, points out that "this often happens in a place where many people do things for a long time with other people" (p. 105). She has in mind a place such as an institution or workplace, but one could argue that an online environment fits the description. The action could be overt or covert, and it makes the bully feel good. The victim is powerless to do anything to the bully. Wierzbicka (2009) argues that bullying is "like what happens when a big animal of one kind ... does something bad for some time to a small animal of some kind" (p. 105). This latter characteristic does not apply to the case of the phenomenon studied in the present research. The victim in fact is not like a "small animal"; he is a person of appreciable status in society, unlike his attackers; however, with their numbers, the accusations and aggressiveness may be said to make him "smaller". Also, it is not necessarily one "big animal" that perpetrates the bullying. As in a school, a group, with a leader, may carry out the action.

A product of the internet era, cyberbullying may be defined as "willful and repeated harm inflicted through the use of computers, cell phones, and other electronic devices" (Hinduja \& Patchin, 2009, p. 11). The principal difference from conventional bullying lies in the medium used by the bully, who, as in the offline environment, seeks to harass and harm a victim. A further difference is that the medium assures anonymity if desired. Such anonymity is a factor in the exercise of a kind of power that does not come with responsibility, and has also been shown to be a feature of the creation and spread of other new media phenomena such as internet memes (Ross \& Rivers, 2017; Ross \& Rivers, 2018). The perpetrator may carry out the bullying both on and offline. Adolescent cyberbullying varies in motivation from the conventional form, according to some studies. Quoting research to date on the myths of cyberbullying, Sabella, Patchin and Hinduja (2013) assert that one common motive for adolescents to engage in cyberbullying is not so much to do harm or exercise domination as to have fun; they are "just playing" (p. 2706).

The ethologist Konrad Lorenz (1991) used the term "mobbing" to describe attacks on a larger single animal by a number of smaller animals, a practice that, interestingly, represents an apt metaphor for the situation explored in the present research. According to Leymann (1996), a psychologist and pioneer in research into this field, "mobbing is characterized by ... socially isolating the victim" (p. 167); it is "ganging up on someone" (p. 165). He prefers to reserve the term "bullying" for the behaviour of children and adolescents at school, where it is often accompanied by violence. The hostile actions of mobbing recur "on a very frequent basis ... and over a long period of time" and has the psychological effect of bringing "social misery" to the victim (p. 168).

Cybermobbing has the same relation to mobbing as cyberbullying to bullying. It is like real-life mobbing in which a victim is bullied by a group of aggressors. In this case, however, the victim may or may not know the perpetrators, who gather online and use the internet to protect their anonymity, which, as pointed out above with regard to cyberbullying, allows the bully to exercise power without responsibility. Wang (2018) proposes that "being part of the mass leads to a mix of power without responsibility, which in turn makes crowd members act in uncontrolled ways" (p. 46). 
The term "cybermobbing" (sometimes with a hyphen) is relatively new in English and little used, perhaps because the concept may be regarded as subsumed within cyberbullying, which after all may also be carried out by more than one person. An American web resource on internet safety certainly accommodates it as a form of cyberbullying, defining it as a type of cyber cruelty that "involves a group sharing the same malicious mindset or intent" (Internet Safety and Cyberbullying Resource for Parents and Schools, n.d.). An internet search reveals a vast amount of commentary on cybermobbing in German, and evidently the word is much more frequently used in Germany and Austria than in Anglophone countries.

A critical aspect of any form of cyberbullying or cybermobbing is the associated verbal aggression. Rösner and Krämer (2016) have explained how in the online context verbal aggression can be either open or covert. Open verbal aggression refers to when a target is attacked directly via chat or message functions. Covert verbal aggression, on the other hand, refers to when the aggression is directed towards a target who is not present; thus, the current study can be said to fall into this latter category. Of interest, however, is that the Facebook group members who are the focus of the study are not attempting to 'hide' in any way, which is what might normally be assumed through the use of the term 'covert'. Research also aligns online such verbal aggression online with the notion of incivility, specifically referring to "features of discussion that convey an unnecessarily disrespectful tone toward the discussion forum, its participants, or its topics" (Coe, Kenski, \& Rains, 2014, p. 660). Lapidot-Lefler and Barak (2012) have taken steps to categorise different types of aggression such as hostile words and expressions, swear words and derogatory names, threats (indirect and direct), symbols and punctuation marks serving to emphasise aggression, and also insulting, sarcastic, teasing, negative, or cynical comments. This prior research is helpful in guiding the present research, as many of these categories can be observed in the data under analysis.

With regard to the general research background for mobbing and cybermobbing, a significant point to make is that studies overwhelmingly take place in the broad fields of psychology and education and tend to have a focus on the effect on the defenceless victim. Leymann (1996) begins his introduction to the phenomenon of cybermobbing with a case description of the victimisation of a woman in her workplace by colleagues and members of senior management. At one point in this woman's story the harassment "developed into a mobbing process" (p. 166). For Leymann (1996) the process entails the gradual loss of the victim's authority and eventual loss of job. While not diminishing the terrible effects of mobbing on a victim, research of the kind undertaken for this paper includes in the scope of the process an inquiry into the nature of the mob; such questions as who comprises it, their motives, and how they interact.

\subsection{Impoliteness}

Cyberbullying is but one of several forms of unwarranted aggression on the internet. Since they are, in all circumstances, a deliberate breach of an established code of politeness, it makes sense to exploit (im)politeness theory as an approach to explaining the sort of discourse behaviour in such instances. Intrinsic to impoliteness, according to Culpeper (2011, p. 23), is "a negative attitude towards specific behaviours occurring in specific contexts". Culpeper goes on to suggest that such behaviours are taken as impolite "when they conflict with how one expects them to be, how one wants them to be and/or how one thinks they ought to be" (p. 23). To be impolite, these behaviours must offend a person or persons. The impoliteness can be aggravated by the extent to which one regards it as "strongly intentional or not" (Culpeper, 2011, p. 23). Culpeper (2011) offers little discussion of bullying but concedes it may be accommodated in his model, fitting into the "diachronic dimension" (p. 257) of impoliteness since it is repeated impolite behaviour over time.

In recent years research has taken up the challenge of exploring impoliteness in the various CMC contexts in which people interact. For example, Kleinke and Bös (2015) investigate intergroup rudeness in German and British discussion fora; Lorenzo-Dus, Blitvich and Bou-Franch (2015) analyse the many offensive postings on a YouTube political advertisement; Dynel (2016a) attempts a close definition of trolling by focusing on the behaviour of one particular troll; and Graham and Hardaker (2017) study the impoliteness of disruptors in online gaming. With regard to Facebook, from which the current research draws its data, Sinkeviciute (2018) explores aggressiveness in participants' commentary on a site that went viral. In surveying the research on impoliteness in $\mathrm{CMC}$, she affirms that impoliteness online has taken root in pragmatics and discourse analysis, though pointing out that it remains an under-researched field of inquiry. Research into the discourse of bullying and cyberbullying appears to be lacking.

From the seminal yet much-criticised politeness theory of Brown and Levinson (1987) one notion may be useful in the discussion of the impoliteness in bullying, "bald on-record". Although the term covers such innocuous face-threatening acts (FTAs) as "Be seated", which may threaten negative face but is polite in the context of, for 
example, a school classroom, it could also apply to the case of a powerful person performing an FTA sure that the victim would not seek to damage the perpetrator's face in return. An instance would be a drill sergeant's insulting and humiliating behaviour towards army recruits, who would not regard such verbal aggression as impolite because this type of behaviour is sanctioned as the norm for the training regime (Mills, 2005, p. 270). As Culpeper (2011) points out, "[i]t is whether the exercise of power is considered an abuse of power ... that heavily determines the judgement of impoliteness" (p. 181). Bullying is an abuse of power, not sanctioned by social norms, not even sanctioned in army recruit training, and is thus impolite; it is also beyond the sphere of bald on-record as conceived by Brown and Levinson (2011).

Culpeper's (2011) definition of impoliteness emphasises that impolite behaviours occur in specific contexts. A lack of consideration of this is one of the drawbacks of Brown and Levinson's (1987) model. They do not take into account that participants in discourse are members of a particular community. In the case of the website under analysis in the present research, it is striking that the participants are members of a closely defined group, more exclusive and cohesive, it may be argued, than a group of colleagues in a given workplace. The group, whose membership does not include the victim, is the context for the interaction in which the participants make and negotiate meaning.

The closeness of the group suggests solidarity, a concept from politeness theory worth exploiting in the present research. It has many applications in the analysis of discourse, for example attending to a hearer's needs or interests, complimenting, and avoiding disagreement. In the case of cybermobbing it could be applied to relations between participants and specifically the language of in-group identity. These participants have a sense of community derived from a common purpose; they have the same views as regards their target and are at ease with one another. In that sense they resemble a sports team in their interactions before and after a match. Holmes (1995) illustrates this sort of solidarity by reference to rugby team members' behaviour in the changing room, characterised, among other things, by an amiable exchange of insults. A more relevant analogy would be the "team spirit" of bullies encircling a victim and exchanging malicious comments with one another about the victim.

This study takes its cue from the specific context in which the impoliteness, the aggressive behaviour, occurs. The context is a community drawn together for a single shared purpose, to attack one individual. In the case of the cybermobbers, the bond is particularly close since they co-operate to attack an individual who is absent and does not respond. This contrasts with other CMC sites where verbal abuse takes place: for example, trolls and flamers leap in among their targets; and commenters on Facebook posts and in discussion boards tend to turn on each other. The task for the present research is to identify and analyse the discourse features that constitute the solidarity of the cybermobbing community. It is hoped this study results in a clearer understanding of cybermobbing, and cyberbullying in general, and of the mentality of the perpetrators.

\section{The Data}

\subsection{The Target}

A Facebook group formed in Australia with the single purpose of vilifying a particular sportsman, Todd Carney, a player in the National Rugby League. In recent years he attracted the attention of the media, especially the tabloid press, and rugby league-oriented social network sites for his misbehaviour off the field, all the result of excessive consumption of alcohol. At the time of writing, he continues his career in Europe. Arguably, he deserved much of the torrent of public disapproval; however, it may be said that the response from the participants of the Facebook group went, in its severity, far beyond the sort of expressions of disapproval sanctioned by society, to the extent that one could regard it as a remarkable phenomenon of organised aggression. Thus, in conducting this study, the focus is not on the target of the cybermobbing but on the behaviour of the cybermobbers.

\subsection{The Text as Data Source}

The text consists of a transcript of a Facebook Chat Group site called "Todd Carney is a Wanker", open to public view, with the description "Join this group if you think Todd Carney is the biggest wanker ever". The site was in existence for at least a year before it was removed. The duration of the site is itself a measure of participants' hostility towards Carney, though comments are not necessarily posted every day. For the sake of a manageable analysis, the text has been divided into four extracts that illustrate the discourse features of the site and of cybermobbing in particular. In total, 47 turns are recorded. For ease of following the text, the sequence of turns has been transcribed in the opposite way to its presentation on Facebook, where the first post chronologically is placed last. Therefore, in this case the first post in the first extract appears earliest and the last at the end. 


\subsection{Participants}

All participants on the site are rugby league fans in eastern Australia, united in their hatred of Carney. The group consists of 1,269 registered members, of whom 42 post comments in the selection for study, 30 of them male and 12 female. The larger number comprises the "mob". Most of the 42 who post in the extracts do so only once, though they may of course post at other times as well due to the asynchronous nature of communication on the platform. There is an administrator of the site who also acts as a moderator; she does not vet comments before submission but from time to time she enters the stream of discourse to give a warning. A significant fact to underline is that almost all the participants offer what appear to be their real names, given and family names, the one exception being someone who calls him or herself "Phouc Ewe". This lack of anonymity will be discussed. In the text in the Appendix A, the names have been changed and only given names used, though the moderator is given a full name, "Bree Hansen".

\subsection{Text Type}

As in all asynchronous $\mathrm{CMC}$, a number of cues integral to speech are absent, for example rhythm and cadence, proxemic arrangements, vocal pitch, and body language. Though not face-to-face, the interaction is naturally occurring and thus has more authenticity as compared with some common sources used in pragmatics research-films, television, letters, emails, and so forth. Furthermore, the analysis cannot be informed by an institutional context such as that of a school or workplace. The text in fact resembles informal conversation but perhaps with more freedom from constraint than usual as the participants, driven by the sole purpose of expressing hostility towards a person not present, feel no need to respond directly to one another, hence the infrequency of adjacency and the lack of coherence.

With regard to the informality of the text, this characteristic fosters an atmosphere in which participants feel that they can say whatever they wish, breaking rules of politeness. Angouri and Tseliga (2010) amply illustrate the contrast, in $\mathrm{CMC}$, between two types of discourse, regulated and formal on the one hand and informal and disordered on the other. Comparing Greek academics' and students' styles of participation in discussion fora, they note that the academics' forum is a place of formal exchange of ideas and of general adherence to netiquette, and breaches of the tacitly accepted norms are not well received by the community. Meanwhile, the students' forum is overwhelmingly informal, and the participants are given to frequent use of taboo language. The participants on the Carney site certainly resemble these Greek students in that respect.

\section{Analysis and Discussion}

For analysis of (im)politeness in texts, Bousfield (2008) proposes the variables that researchers should take account of at the outset: discoursal roles, past encounters of interactants ("participants" in this paper), demographics of the interactants, the cultural frame of communication, topic control, and turn-taking. Discussing these variables helps to distinguish this text from other CMC texts in which aggression takes place and serves to introduce the analysis.

The discoursal roles are the participants on the site who post comments. Included among them is the moderator, who is not, as one finds on more regulated sites such as newspaper reader response sections (Neurauter-Kessels, 2011), an external arbiter. Addressees play another role. The participants' addressees are one another but also, indirectly, the entire readership. One of the addressees who may be a reader is the target of all the abuse, Todd Carney. He is addressed indirectly in the sense that interactants refer to him most of the time in the third person.

Regarding past encounters of participants, since the site is a place of regular meeting over a period of at least a year, participants come to recognise one another, and new contributors seem to be welcome as long as their posts match the purpose of the site. Furthermore, as committed fans of a particular code of rugby in eastern Australia, they probably never feel "strangers" to one another.

This sense of tight community begins an answer to the question of the demographics of the participants and cultural frame of communication. The obsession with club rugby that the contributors share gives them an inherent homogeneity, a factor in the solidarity behaviour that emerges in the discourse. The majority, if not all, of them live in eastern Australia where the sport is dominant and are likely to have communicative styles and cultural norms in common. With respect to cultural norms, however, it may be said that they know them well enough to breach them, exactly like groups such as friends in a pub who give themselves over to excessive profanity or school students who steal away to smoke cigarettes. The illicitness is "part of the culture" in a sense.

Topic control is managed on an official level by an "Administrator" who is also a participant. She steps into the exchanges in order to ensure relevance of contribution and steer interlopers away. At one point, for example, she intervenes with "THIS IS 4 - NON CARNEY FANS... ALL OTHERS LEAVE” (Turn 18 [T18]). However, 
participants themselves, in an instance of solidarity, may show little tolerance of anyone who fails to share the group's view. As Carl says, "This is for ppl that think hes a wanker!!!!” (T12).

Self-evidently, turn-taking cannot be as in normal conversation or discussion. On this site it is governed by the asynchrony of CMC and the "non-linearity of communication" (Neurauter-Kessels, 2011, p. 193): the stream of posts is only intermittent, and they do not always respond to one another, the participants most of the time posting independent comments. That said, there is some attempt at "discussion", notably in Natasha's turns (T43, T45, and T47).

The account of the variables of past encounters, demographics, cultural frame, and even topic control suggests quite a robust sense of community; thus, evidence of solidarity in the discourse should be identifiable. Turn-taking seems to be the exceptional variable in this respect. It is clear that not much "conversation" or exchange takes place. Some brief interactions occur, for example from T13 to T16. Natasha's long turns (43 and 45) elicit no direct response to her ideas, so would not constitute "discussion" as such. Turns 11 to 16 over two days in April show the longest phase of interaction Therefore, while turn-taking behaviour is commonly regarded in research as revealing the extent of solidarity between participants (Koudenberg, Postmes, \& Gordijn, 2013), often supported through accompanying paralanguage or gesture (Sikveland \& Ogden, 2012), the turn-taking on the Carney site would not be such a source. With participants not sharing the same time and space and supporting paralanguage thus being unavailable, the evidence of solidarity in the group lies elsewhere in the text.

A number of likes occur in the text (Ts 4, 19, 29, 39, 41, 43, 45) that may be conceived as part of the turn-taking in the sense that they are responses to utterances, backchannel cues equivalent in oral discourse to listenership, and reinforcing solidarity. However, according to Burrell and Rainone (2017), if one has a sense of purpose in using social media, one is less concerned with the number of likes that one gets and not reliant on them for self-esteem. The strong sense of purpose among participants on the Carney site could be said to render the likes, relatively few as there are, less significant than on sites where acceptance by others has high value, for example on a personal Facebook page. In general, evidence of solidarity lies in other aspects of the Carney group's discourse than turn-taking.

\subsection{Non-Anonymity and Solidarity}

Before proceeding further in the analysis, it is worth paying attention to a prominent non-linguistic feature of the text, that, with the one exception mentioned earlier, the participants freely give their real names. Since anonymity removes a good deal of self-restraint in expressing oneself, especially in an aggressive context, it is surprising perhaps that the participants in the Carney text do not adopt it. The phenomenon known as the online disinhibition effect (ODE) (Suler, 2004) allows internet users to act without restraint, for example in expressing themselves candidly in a way they would be reluctant to do in real life. But in its toxic form, under the cloak of anonymity, it can encourage them to engage in aggressive behaviour, such as in cyberbullying, with no fear of the consequences. It is worth proposing that a sense of community and solidarity derived from a common purpose has encouraged participants on the Carney site to dispense with the option of anonymity. In this sense they resemble a group of school bullies who crowd around a victim. They are known to their victim and to peers who may be watching, but they do not fear punishment.

\subsection{Profanity and Solidarity}

Abusive language lies at the heart of the impoliteness in the text; it is strongly intentional, power-building, face-threatening, and in conflict with social norms. The abuse frequently takes the form of profanity, of which the use of expletives is a salient instance. According to de Klerk (1997, p. 147), "the use of expletives has a covert attraction because of its connotations of strength, masculinity and confidence in defying linguistic or social convention".

As one might expect of a text like this, the Carney site abounds with profanity. Individual swear words are common. There is the much-repeated wanker as well as fuckwit, shit, and douche bag. Much more confronting, however, are the more elaborate expressions of hate such as the following stream of consciousness:

38 Doug what a fuckwhit carney is the oxygen thief, sacked, had chance to start a fresh in uk with giants fucked that up, got third chance and surprise fucked up again wants putting down immature retard the question is who, $\mathrm{s}$ next him again or that other dickhead and his nutter missus greg bird, pair off dicks who super league are better off without

\section{January 25 at $12.05 \mathrm{pm}$}

This tirade is an intensification of the profanity, longer than most other contributions to the site, and comprises not only individual expletives but also some narrative and comment. A shorter but also inventive post is Jonah's: 
39 Jonah Todd carney ur a shit footballer and a fuck wit dog cunt give up fuck wit

\section{March 6 at $5.09 \mathrm{pm}$}

Bree Hansen likes this.

In the above two instances the lack of syntax shows the disregard for both social and linguistic convention. Jonah could have been trying to mimic someone who is stuttering and inarticulate with hot anger. Interestingly, the creator of the site adds her like, a sign that she approves of this style of attack. Given the extreme nature of the profanity, it also leads one to wonder what exactly might elicit a warning from the moderator. Even more liked is Graeme's comment:

41 Graeme He was a waste of a perfectly good fuck. The load his mother should have swallowed.

April 14 at $12.58 \mathrm{pm}$

5 people like this.

42 Steve ahhahaha funny shit

April 14 at $1.19 \mathrm{pm}$

These positive responses, the highest number in the extracts, reflect appreciation of the humour in the obscenity.

Jonah's use of the personal second-person singular in his attack is unusual in a text in which the great majority of participants opt for third-person declarative speech acts. Paolo's posts (T9 and T17), only slightly less intense in profanity, are the two other examples. Although the three contributions target Carney directly, as if he were present, they are clearly intended for the appreciation of the audience on the site in the same way that Doug's and Graeme's are. Indeed, it may be said that, the three participants are seeking to amuse the audience, very successfully in Graeme's case.

As regards female use of profanity by comparison with male, the low number of women on the site, offering about $26 \%$ of the turns, cannot allow generalisation. According to the stereotype, swearing is one of the features of language that reflect masculinity (Mills, 2005). What can be said is that the women in the text tend to fewer and milder profanities, for example "such a dick" (T5) and "hot shit" (T37), the most severe one being "farkin douche" (T23), in which the strength of the swear word is diluted by the deliberate misspelling. The pattern of swearing in the text lends support to the notion that "men use more offensive language than women" (Jay \& Janschewitz, 2008, p. 272), even if they swear at the same rate.

The profanity on the site intends not only to give offence but also to reinforce the solidarity felt by the participants. According to Allan and Burridge (2006, p. 77), "swearing can act as an in-group solidarity marker with shared colloquial style". Social swearing (Dynel, 2012; Montague, 1967; Wajnryb, 2005) is a term referring to this practice, one that arises in environments on minimal social distance, and where camaraderie reigns. The social swearing on the Carney site resembles that of workers on the factory floor such as those studied by Daly, Holmes, Newton and Stubbe (2004) whose frequent use of the word fuck links them together in a community of practice.

\subsection{Play, Humour, and Solidarity}

The reference above to amusing the audience serves as an indication of solidarity. Although the participants dedicate themselves to an unorganised virulent assault on a particular target, their equal purpose appears to be to engage in the community created for them by the website. They enjoy it together. Jacinta, addressing the creator, says, "Well done love....best group made by far" (T5) and Ian echoes this: "this is the best group ever!" (T21); they even shoo away those who do not belong:

12 Carl dude if u love him so much go make your own I LOVE TODD CARNEY fan clud, this is for ppl what think hes a wanker!!!!

April 8 at 11.08am

Carl is responding to Josh:

11 Josh But Todd Carney is my hero! How could any of you possibly put a bad word to his name?

April 8 at $12.39 \mathrm{am}$

It is most likely that Josh is being ironic. Carl might be playing along or taking Josh literally; whichever the interpretation, Josh is trying to raise a smile, playing with the language in the same spirit as Graeme and Jonah. It seems that most participants on the site make an effort, with their comments, anecdotes and reports, to attract attention and hold interest. This could be with a dry comment such as "set fire to anyone else lately" (T35) or 
with excessive exclamation as in "LOSER WANKER!!!" (T24) and "I can n ot believe the roosters signed him!!! (T36). Ultimately, participants give the impression that they take pleasure in the site, many of them having fun, and appreciating the humour or wit that any of them offer. It is interesting then that Natasha's "serious" comments (T43 and T45), lacking obscenity and playfulness, seem out of place.

Analysing the nature of the humour in the television series House, Dynel (2016b) identifies it as residing in the protagonist's impoliteness; in doing so, she throws light on the role humour plays in the impoliteness embodied in the mobbing interaction in the Carney text: it takes the form of humorous disparagement, wherein the humour targets a victim, "typically other than the hearer whom the speaker intends to amuse" (p. 137). She claims that the speaker characteristically seeks to offend the target, who may or may not be present, and this "serves as a springboard for the humour to be appreciated by the (other) listeners" (p. 137). Impoliteness becomes the entertainment and reinforces solidarity between participants.

Reviewing research to date on humour and play in CMC, Vandergriff (2010) emphasizes two features commonly associated with them, aggressiveness and co-operativeness. These characteristics certainly combine in the Carney text, with participants co-operating in play that is entirely hostile to another person. The word "play" in CMC evokes online gaming environments where users adopt a new identity, even a different gender or a non-human. The cybermobbing site does not exhibit identity play (Vandergriff, 2010) in the manner of an online game; however, it does show participants who, liberated from the moral order that controls their day-to-day lives, adopt and enjoy the transgressive role of abusers. The ODE facilitates this liberation, even if real names are used.

\section{Conclusions}

This article has explored an instance of cybermobbing in the context of a Facebook group targeting Australian professional rugby league player, Todd Carney. Members of the group are flagrant in their display of impoliteness, their behaviour conflicting with how one thinks they ought to behave (Culpeper, 2011). Revolving around their shared hatred of Carney, they seem to revel in their non-anonymity, allowing their visible personal identities to become a shared group identity, which is the first level of solidarity established within the group. The non-anonymity makes them more "ordinary" than those under cover of assumed names, ordinary people who allow extraordinary aggression in their language. The members also forge their sense of solidarity through a shared use and acceptance of profane language and labelling; it is language that would be offensive to anyone on the receiving end, but for the espousers it forms part of the bond. Also highlighted are the ways in which the group members engage in play and interact in a humorous manner as a means of further developing the solidarity among themselves.

Reflecting upon the data, one may consider again the positions of both the target and group members. Carney himself is a serial misbehaver, and would have offended some in the group if he tarnished the name of the team that they support. All members would be offended if he did the same thing to the name and reputation of the game they love. Nonetheless, here he is sought out within this new media context by a group of aggressors and targeted. This hostility is expressed within the group, about Carney, but not to him. They are like school bullies insulting the victim and spouting rumours about him, not to his face but in interaction with each other. Such aggression benefits the group; they are sustained by it and become comfortable among like-minded rugby league fans.

However, one should also consider the fact that Carney is in all likelihood completely unaffected by this group and their discourse. It is indeed possible he does not even know of the group's existence and thus their barbs will inflict no damage to him personally. When viewed in this way, it helps to strengthen the argument that although the mob have descended on Carney, they have not done so in a serious attempt to destroy him, but rather to foster and enjoy the in-group solidarity they have formed. The enjoyment of the group forms part of the definition of this type of cyberbullying. Future research into cybermobbing that seeks to explore the impact of such groups on the targeted individuals themselves would be a useful step towards an even deeper understanding of the act of cybermobbing in social media settings.

\section{References}

Angouri, J., \& Tseliga, T. (2010). "You Have No Idea What You are Talking About!”: From e-disagreement to e-impoliteness in two online fora. Journal of Politeness Research, 6(1), 57-82. https://doi.org/10.1515/jplr.2010.004

Bousfield, D. (2008). Impoliteness in interaction. Amsterdam: John Benjamins. https://doi.org/10.1075/pbns.167

Brown, P., \& Levinson, S. (1987). Politeness: Some Universals in Language Use. Cambridge: Cambridge University Press. https://doi.org/10.1017/CBO9780511813085 
Burrow, L., \& Rainone, N. (2017). How many likes did I get? Purpose moderates links between positive social media feedback and self-esteem. Journal of Experimental Social Psychology, 69, 232-236. https://doi.org/10.1016/j.jesp.2016.09.005

Coe, K., Kenski, K., \& Rains, S. A. (2014). Online and uncivil? Patterns and determinants of incivility in newspaper website comments. Journal of Communication, 64, 658-679. https://doi.org/10.1111/jcom. 12104

Culpeper, J. (2011). Impoliteness: Using Language to Cause Offence. Cambridge: Cambridge University Press. https://doi.org/10.1017/CBO9780511975752

Daly, N., Holmes, J, Newton, J., \& Stubbe, M. (2004). Expletives as solidarity signals in FTAs on the factory floor. Journal of Pragmatics, 36(5), 945-964.

de Klerk, V. (1997). Expletives and masculinity. In S. Johnson \& U. H. Meinhof (Eds.), Language and Masculinity (pp. 144-158). Oxford: Blackwell.

Dynel, M. (2012). Swearing methodologically. The impoliteness of expletives in anonymous commentaries on YouTube. European Journal of English Studies, 10, 25-50. https://doi.org/10.18172/jes.179

Dynel, M. (2016a). "Trolling is not stupid": Internet trolling as the art of deception serving entertainment. Intercultural Pragmatics, 13(3), 353-381. https://doi.org/10.1515/ip-2016-0015

Dynel, M. (2016b). Conceptualizing conversational humour as (im)politeness: The case of film talk. Journal of Politeness Research, 12(1), 117-147. https://doi.org/10.1515/pr-2015-0023

Graham, S. L., \& Hardaker, C. (2017). (Im)politeness in digital communication. In J. Culpeper, M. Haugh \& D. Kádár (Eds.), The Palgrave handbook of linguistic (im)politeness (pp. 785-814). London: Palgrave Macmillan. https://doi.org/10.1057/978-1-137-37508-7_30

Hardaker, C. (2010). Trolling in asynchronous computer-mediated communication: From user discussions to academic definitions. Journal of Politeness Research, 6, 215-242. https://doi.org/10.1515/jplr.2010.011

Hinduja, S., \& Patchin, J. W. (2009). Bullying beyond the schoolyard: Preventing and responding to cyberbullying. Thousand Oaks, CA: Sage Publications (Corwin Press).

Holmes, J. (1995). Women, men and politeness. Longman: London and New York.

Internet Safety and Cyberbullying Resource for Parents and Schools. (n.d.). Retrieved from http://www.internetsafetysource.com/cyber-mobbing.html

Jay, T., \& Janschewitz, K. (2008). The pragmatics of swearing. Journal of Politeness Research, 4, 267-288. https://doi.org/10.1515/JPLR.2008.013

Kleinke, S., \& Bös, B. (2015). Intergroup rudeness and the metapragmatics of its negotiation in online discussion fora. Pragmatics, 25(1), 47-71. https://doi.org/10.1075/prag.25.1.03kle

Koudenberg, N., Postmes, T., \& Gordijn, E. (2013). Conversational flow promotes solidarity. PLoS One, 8(11), e78363. https://doi.org/10.1371/journal.pone.0078363

Lapidot-Lefler, N., \& Barak, A. (2012). Effects of anonymity, invisibility, and lack of eye-contact on toxic online disinhibition. Computers in Human Behavior, 28, 434-443. https://doi.org/10.1016/j.chb.2011.10.014

Leymann, H. (1996). The content and development of mobbing at work. European Journal of Work and Organizational Psychology, 5(2), 165-184. https://doi.org/10.1080/13594329608414853

Lorenzo-Dus, N., Garcés-Conejos Blitvich, P., \& Patricia Bou-Franch, P. (2011). On-line polylogues and impoliteness: The case of postings sent in response to the Obama Reggaeton YouTube video. Journal of Pragmatics, 43(10), 2578-2593. https://doi.org/10.1016/j.pragma.2011.03.005

Mills, S. (2005). Gender and impoliteness. Journal of Politeness Research, 1, 263-280. https://doi.org/10.1515/jplr.2005.1.2.263

Nansel, T. R., Overpeck, M., Pilla, R. S., June Ruan, W., Simons-Morton, B., \& Scheidt, P. (2001). Bullying behaviors among U.S. youth: Prevalence and association with psychosocial adjustment. Journal of the American Medical Association, 285(16), 2094-2100. https://doi.org/10.1001/jama.285.16.2094

Neurauter-Kessels, M. (2011). Im/polite reader responses on British online news sites. Journal of Politeness Research, 7(2), 187-214. https://doi.org/10.1515/jplr.2011.010

Rösner, L., \& Krämer, N. C. (2016). Verbal venting in the social web: Effects of anonymity and group norms on aggressive language use in online comments. Social Media + Society, 2(3). 
https://doi.org/10.1177/2056305116664220

Ross, A. S., \& Rivers, D. J. (2017). Digital cultures of political participation: Internet memes and the discursive delegitimization of the 2016 U.S Presidential candidates. Discourse, Context \& Media, 16(1), 1-11. https://doi.org/10.1016/j.dcm.2017.01.001

Ross, A. S., \& Rivers, D. J. (2018). Internet memes as polyvocal political participation. In D. Schill \& J. A. Hendricks (Eds.), The Presidency and social media: Discourse, disruption and digital democracy in the 2016 Presidential election (pp. 285-308). New York, Routledge. https://doi.org/10.4324/9781315112824-15

Sabella, R. A., Patchin, J. W., \& Hinduja, S. (2013). Cyberbullying myths and realities. Computers in Human Behavior, 29, 2703-2711. https://doi.org/10.1016/j.chb.2013.06.040

Sikveland, R. O., \& Ogden, R. (2012). Holding gestures across turns. Gesture, 12(2), 166-199. https://doi.org/10.1075/gest.12.2.03sik

Sinkeviciute, V. (2018). 'Ya bloody drongo': Impoliteness as situated moral judgement on Facebook. Internet Pragmatics, 1(2), 271-302. https://doi.org/10.1075/ip.00013.sin

Suler, J. (2004). The online disinhibition effect. Cyber Psychology \& Behavior, 7(3), 321-326. https://doi.org/10.1089/1094931041291295

Vandergriff, I. (2010). Humor and Play in CMC. In R. Taiwo (Ed.), Handbook of research on discourse behavior and digital communication: Language structures and social interaction (pp. 235-251). IGI Global. https://doi.org/10.4018/978-1-61520-773-2.ch015

Wang, Z. M. (2018). Anonymity effects and implications in the virtual environment: From crowd to computer-mediated communication. Social Networking, 7, 45-62. https://doi.org/10.4236/sn.2018.71004

Wierzbicka, A. (2009). The language of "bullying” and "harassment" (pp. 102-107). Quadrant, December.

\section{Appendix A}

\section{Facebook Chat Group}

\section{TODD CARNEY IS A WANKER}

Category:

Sports \& Recreation - Sports Leagues

Description:

\section{JOIN THIS GROUP IF YOU THINK TODD CARNEY IS THE BIGGEST WANKER EVER}

Privacy Type:

Open: All content is public.

\section{Admins}

Bree Hansen (creator)

\section{Members}

1 of 1,269 members

Extract 1

\section{Callum LOSER!}

April 4 at 5:06pm

2 Matthew what a wanker had everything pissed it all a way. This is what happens to people when they think there bigger then the game. They turn to big head wankers.

April 4 at $6.50 \mathrm{pm}$

3 Tom he took a picture of himself nude holding his cock... says it all really.

April $511.53 \mathrm{pm}$

4 Dan any guy that has been banned from every place in goulbourne must be a wanker

April 6 at $4.05 \mathrm{am}$ 
2 people like this.

5 Jacinta Bree! Well done love... best group made by far.

anyone who spits on women at a pub then 20 mins later pisses on someone else deserves to be shot.

such a dick!

April 6 at $10.48 \mathrm{pm}$

6 Jared Why do so many people dislike this todd carney bloke????? who is he??? whats he done????? is he a cabbie?

April 7 at $1.15 \mathrm{am}$

7 Bree Hansen goggle his name hehe

April 7 at $7.49 \mathrm{pm}$

8 Andy absolute fuckwit

April 7 at $8.34 \mathrm{pm}$

9 Paolo your fucn nowhere carney who the fuc do u think u r!!!! disloyal $\mathrm{c}^{* \# t !}$

April 7 at 9.06

10 Nick must be pretty embarrassing to be banned from your home town... particularly since his home town is Goulbourn...

April 7 at $9.25 \mathrm{pm}$

11 Josh But Todd Carney is my hero! How could any of you possibly put a bad word to his name?

April 8 at $12.39 \mathrm{am}$

12 Carl dude if u love him so much go make your own I LOVE TODD CARNEY fan clud, this is for ppl what think hes a wanker!!!!

April 8 at $11.08 \mathrm{am}$

13 Rick CARNEY'S A WANKER haha who gets banished anymore? It must be the first time in a century that NSW has gone medieval like that.

April 8 at 12.49

14 Kyle To bad he's a good as footy player

April 8 at $1.44 \mathrm{pm}$

15 Kyle raiders shouldn't of let him go

April 8 at $1.48 \mathrm{pm}$

16 Seb yea, too bad raiders lost him, he is a good as footy player, but such a wanker

April 9 at $8.38 \mathrm{pm}$

17 Paolo you're a fn wanker carney n so r u rocky

April 9 at $8.38 \mathrm{pm}$

18 Bree LMFAO... THIS IS 4 - NON CARNEY FANS... ALL OTHERS LEAVE

April 10 at $10.55 \mathrm{pm}$

Extract 2

19 Kiaran Must have pissed on someone... again

Todd Carney bashed after party / Daily Telegraph www.news.com.au

TODD carney will abandon nights out for the remainder of his stay in Atherton after being bashed at the weekend.

May 13 at $5.48 \mathrm{pm}$

Mandy likes this.

20 Caitlyn I see that the stupid wanker is in trouble yet again...... There has been talk about him signing with the Roosters, my daughter is a Rooster supporter and is praying that its not true.... dispite the fact if he can play 
or not... would it be worth the risk that hes gunna do something stupid!

I bet that when he was a kid he was one of those grotty little snotty nosed boys who picked their scabs and ate flys.

May 15 at $11.49 \mathrm{am}$

21 Ian this is the best group ever!

May 17 at $11.22 \mathrm{pm}$

22 Kirsten I think most women in Atherton hate Tod Carney... LMAO.

May 30 at $5.56 \mathrm{pm}$

23 Eliyse Jacko - unfair comment brother, I am from Goulburn and I am not a farkin douche like Todd...I think you will find majority of Goulburn think Todd is a total knob end!

June 2 at $9.12 \mathrm{pm}$

24 Renee yeah I agree... LOSER WANKER!!!

June 11 at $1.38 \mathrm{pm}$

25 Phouc Ewe It's good to see that Todd has been dealt a bit of Karma. Obviously todd didn't have any of his fuckwit mates there to help him out. residents of Atherton there was a rumour that Todd was gay (this was an alleged incident @Tha Dirty Bird) so watch out Fella's.

June 11 at $4.47 \mathrm{pm}$

26 Darren HAHAHA Classic ad at the top of the page. Still got a copy on my wall at work! How someone earning 6 figures needed so many chances still amazes me.

Q. I'll pay you a shite load to do what you love, just don't drink....DONE!

June 25 at $2.33 \mathrm{pm}$

27 Jessica who is todd carney

July 8 at $11.28 \mathrm{am}$

28 Sean If you go to the mens bathroom at the front of All Bar in O'conner ACT, you will find some hilarious graffiti explaining why $\mathrm{mr}$ carney is such a wanker. I didn't do it, and I think the individual who did, is nearly as brain dead as Todd himself, but, it is enjoyable nonetheless.

July 13 at $2.07 \mathrm{am}$

Extract 3

29 Terry brain dead fuckwit should have been shot on his mothers tits

January 4 at $9.52 \mathrm{pm}$

2 people like this.

30 Kel Apparently all the Carneys are wankers mate

January 7 at $4.25 \mathrm{pm}$

31 Gary LOL it's a mile a minute with this guy..... Crazy. You think he would have learnt his lesson by now.

January 5 at 10.07 am

32 Tom my bet is todd will pay the bloke off like he did when he pissed on that blokes head. Roosters deserve everything they get.

January 5 at $3.57 \mathrm{pm}$

33 Jennie Why won't they sack him.....

January 5 at $11.01 \mathrm{pm}$

34 Maddy He's becoming a lost cause, honestly I wouldn't bother.

January 5 at $11.27 \mathrm{pm}$

35 Mario set fire to anyone else lately

January 9 at $12.00 \mathrm{pm}$ 
36 Alison I can n ot believe the roosters signed him!!! what are they trying to do?? make their team worse??? biggest douche bag ever to come out of and disgrace Canberra!!

January 16 at $9.47 \mathrm{am}$

37 Rose Feel sorry for some of us in Atherton who actually cant stand the toss he is rude disrespectful Slyney should of knocked him out better and god you have never met a guy more up himself thought he was hot shit but there are some idiots here who thinks the sun shines out of his arse

January 17 at $6.24 \mathrm{pm}$

38 Doug what a fuckwhit carney is the oxygen thief,sacked,had chance to start a fresh in uk with giants fucked that up,got third chance and surprise fucked up again wants putting down immature retard the question is who,s next him again or that other dickhead and his nutter missus greg bird,pair off dicks who super league are better off without

January 25 at $12.05 \mathrm{pm}$

Extract 4

39 Jonah Todd carney ur a shit footballer and a fuck wit dog cunt give up fuck wit

March 6 at $5.09 \mathrm{pm}$

Bree Hansen likes this.

40 James At least Goulburn had the sense to run him out of town

March 18 at 11.32

Phillip likes this.

41 Graeme He was a waste of a perfectly good fuck. The load his mother should have swallowed.

April 14 at $12.58 \mathrm{pm}$

5 people like this.

42 Steve ahhahaha funny shit

April 14 at $1.19 \mathrm{pm}$

43 Natasha I don't care how good a player Tod Carney may or may not be, as a person he is a complete and utter idiot and off the field he is an absolute disgrace. Personally I think he should be banned from the NRL, if they're serious about wanting to change their image first step should be to get rid of this 6 time loser $(7,8 \ldots 9 \ldots$ Actually I've lost count, what chance is he on right now???)

April 19 at 3.18

Con likes this.

44 Con hope this loser gets fired from the NRL and never comes back, he is a disgrace to the NRL!

April 19 at $7.15 \mathrm{pm}$

45 Natasha Just saw the news, apparently he has to undergo psychiatric evaluation then they'll make a decision. Pretty simple diagnosis really, he's a wanker and a complete drop kick. Yes, he probably does have a problem with alcohol and isn't able or willing not to drink, so stick him in a rehab centre somewhere, surely he can afford to the very best one available... That is if he hasn't drunk away his ridiculous sums of money. Tho from what I've heard the alcohol merely increases the level's of wankdom that are always present.

April 19 at $8.07 \mathrm{pm}$

Jeff likes this.

46 Ken Once again he proves the page title correct

April 21 at 1.23

47 Natasha Ahh Carney, you dipshit...

Beetson: tear up Carney's contract

www.theaustralian.com.au

LEGENDARY Eastern Suburbs forward Arthur Beetson believes the Roosters have been left with no choice but to sack Todd Carney after the troubled five-eighth yet again betrayed the trust of his teammates. 


\section{August 13 at $3.24 \mathrm{pm}$}

\section{Copyrights}

Copyright for this article is retained by the author, with first publication rights granted to the journal.

This is an open-access article distributed under the terms and conditions of the Creative Commons Attribution license (http://creativecommons.org/licenses/by/4.0/). 